East German waste

\section{Water may not be polluted}

EAST GERMANY (GDR) "has none of the toxic waste problems reported in other countries", the Minister of Environmental Management and Water Protection, Dr Hans Reichelt, stated recently. He was referring to what the official news agency ADN called "reports by the Western media concerning toxic by-products", presumably a reference to the reports from West Berlin last autumn that the dumping of industrial wastes in East Germany was causing pollution of groundwater, the major part of East Germany's water supply. Heavy metal contamination, it was claimed, was causing special concern.

According to Dr Reichelt, however, dumping takes place only under strict control, and toxic wastes are either partially burned to produce energy or else "stored in such a way as to exclude any danger to the environment",

The West German concern about possible dumping in East Germany has more than a propaganda significance, however. Under the terms of recent agreements between the two Germanies, water is supplied through long-distance pipelines from the Ecker dam which spans the frontier. For his part Dr Reichelt stated specifically that East Germany was "remote from any propaganda demonstration", and was prepared to enter into cooperation with any interested countries.

The East German record over the past few years shows considerable effort. Since the 1960s, agreements with West Germany and with Poland have regulated antipollution work in the frontier rivers and, more recently, agreements have been concluded with the Federal Republic on the waters which actually cross the frontier. There are joint projects between the two Germanies on the reduction of pollution in the Steinach and Werra, and the East German government has stated its willingness to engage in consultations on the protection of the Elbe, which, the West Germans complain, is heavily contaminated with cadmium.

Moreover - and this is a far more sensitive issue politically - East Germany recently entered into an agreement with the senate of West Berlin on preventing water pollution. As a signatory to the Helsinki Convention on the Baltic of 1974, East Germany has committed itself to reducing the pollution level of rivers flowing into the Baltic and this is being done, albeit slowly.

The main problem, however, is not reducing the pollution entering the rivers but protecting the groundwaters before they get to the river. Dr Reichelt admitted the urgent need for low-residue technologies, particularly in the chemical, energy, metallurgy, iron ore mining, potash and ceramics industries. Vera Rich

Biotechnology Celltech fights the bottom line

CELLTECH, Britain's own green-field biotechnology corporation, doubled its trading loss in the year to the end of November 1982, but increased its earnings from the sales of products by a factor of five to $£ 384,000$, roughly a fifth of the net loss during the year. In the circumstances, it will be widely understood that the company has not made provision in last year's accounts for the ravages that taxation wreaks on profitable companies. Indeed, Celltech's tax losses appear to have increased over the year by $£ 2.1$ million, rather more quickly than its accumulated deficit. This seems well in line with the performance of other new biotechnology companies.

The bad news is twofold: Celltech's chairman, Mr H.W. Denham of the British and Commonwealth Shipping Company, one of the original shareholders, resigned at the end of November on the grounds of the time required and the importance of avoiding conflicts between the chairman and major shareholders. But the company has also had to call up a further 29 per cent of the $£ 11.5$ million its shareholders had originally promised, so that only a third of the company's potential capital remains untouched.

The chances that Celltech can get by without asking its shareholders to stump up more than their promised capital therefore depend critically on the company's trading prospects for the present year. The annual report published last week is optimistic about the prospect of rapid growth in the sale of diagnostic aids, among which the reagents for the recognition of the $\mathrm{A}, \mathrm{B}$ and $\mathrm{O}$ blood-groups predominate. The annual report also mentions the manufacture of peptides as a potential growth area, saying that the company will ordinarily offer such developments as licensing packages but citing chymosin (rennin) as one now on offer.

The annual report also gives the lie to rumours that Celltech is a kind of Eldorado for emigrant molecular biologists returning to the United Kingdom. Last year, Celltech's managing director, Mr Gerald Fairtlough, appears to have earned just over $£ 36,000$ while Dr Norman Carey, its research director, had his salary increased to more than $£ 30,000$ (but less than $£ 35,000$ ).

\title{
US fire research Dismay at research cutback
}

\section{Washington}

FIRE researchers have reacted with incredulity to a Reagan Administration proposal to eliminate the Center for Fire Research at the National Bureau of Standards (NBS) on the grounds that its work could be carried out by private enterprise or state and local governments.

The centre, with a staff of about 100 and an annual budget of $\$ 5.9$ million, is widely respected for its scientific expertise and for its objectivity in an area choked with the competing claims of building-materials manufacturers each arguing the fire safety of its own products. It is also the only major laboratory studying residential fires.

The Administration's proposal to cut off funding for the centre in the 1984 budget has left the fire community more amazed than angry. And at a Senate hearing last week, it became clear just how little thought the Administration had given to the decision. The director of NBS, Ernest Ambler, while being careful not to question the party line, made it clear that no study had been made of the private sector's interest or willingness to take up the research now done at NBS. "I'd hope that they might take up some of it", he said. "You'd hope they might take up some of it?" Senator Slade Gorton (Republican, Washington) asked in amazement.

In fact, according to several key figures in the fire research community, the prospects are exceedingly dim that even part of the centre's work would find its way into the private sector. The kind of work done at the centre - including the development of standard testing methods for materials and smoke detectors, mathematical modeling of fires, fundamental studies of combustion and flame spread in buildings and studies of smoke toxicity - does not match the capabilities or the interests of private groups, they say.

According to Professor Howard Emmons of Harvard University, a long-time fire researcher, industry laboratories are concerned almost exclusively with testing specific products. Factory Mutual, an insurance group founded by industry to provide industrial fire insurance, runs "probably the best industry fire research system in the country", Emmons says; but "they're small compared to the Bureau of Standards" and "they do nothing about life-loss or toxicity" - only loss of property.

A private organization is also unlikely to supply the $\$ 2$ million a year that NBS currently provides for the support of basic fire research at universities.

Emmons added that it is simply unrealistic to expect the residential fire insurance companies to take over the support of fire research: "There is no question that nothing does the fire insurance industry as much good as a humdinger of a fire"

Others pointed to the value of the centre's objectivity - something that private enterprise could not replace. On the issue 
of smoke toxicity - which has pitted the plastics industry against the steel industry over the use of plastics in electrical conduit and other building applications - the centre is "the only credible source of technical information", according to the National Fire Protection Association, a non-profit organization that writes widely-used model fire codes.

Even the plastics industry, which had lodged strong objections to the centre's work on smoke toxicity, issued a statement from its trade association, the Society for Plastics Industry, asking for "serious reconsideration" of the decision to eliminate the centre.

Just why the Administration decided to single out fire research is unclear. Dr Fred Clark, former director of the centre and now a private consultant, said he doubted that concern over the projected $\$ 200,000$ million federal deficit could really have been the issue. "All the Reagan Administration has to do is find 40,000 more issues like the Center for Fire Research and they can balance the budget", he said.

NBS is also facing the loss of its Center for Building Technology in the 1984 budget, a 70 per cent cut in its Institute for Computer Science and Technology (which is developing compatibility standards for the computer industry) and substantial cuts in the Standard Reference Materials and Measurements Assurance Programs, with the funding to be made up by increased "user fees".

\section{Saleroom news}

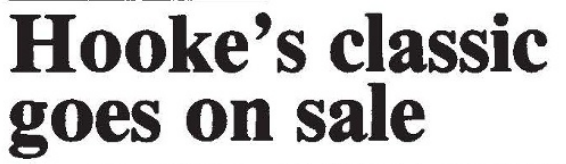

A FIRST edition of Robert Hooke's Micrographia, a work which heralded the birth of scientific microscopy, is to be auctioned this week at Christie's saleroom in London. The auctioneers estimate that the volume will fetch between $£ 3,000$ and $£ 4,000$, which seems a moderate price for such a rare item.

The full title of Hooke's historic work, first published in 1665, is impressive: Micrographia, or some physiological descriptions of minute bodies made by magnifying glasses with observations and enquiries thereupon. It was the first book in English devoted to microscopy and it is enriched by many superb copperplate illustrations in Hooke's own hand. Two drawings in particular - showing a flea and a louse enlarged to about 20 inches in length - created considerable interest when the book was published.

Unfortunately, Hooke's original microscope has not survived but from his extremely clear drawing and description it is seen to have possessed a screw focusing arrangement, and a ball and socket joint providing inclination of the body tube. The stage was an innovation, as was the means of illumination.

Hooke may be remembered in some

\section{Women in science in the United Kingdom}

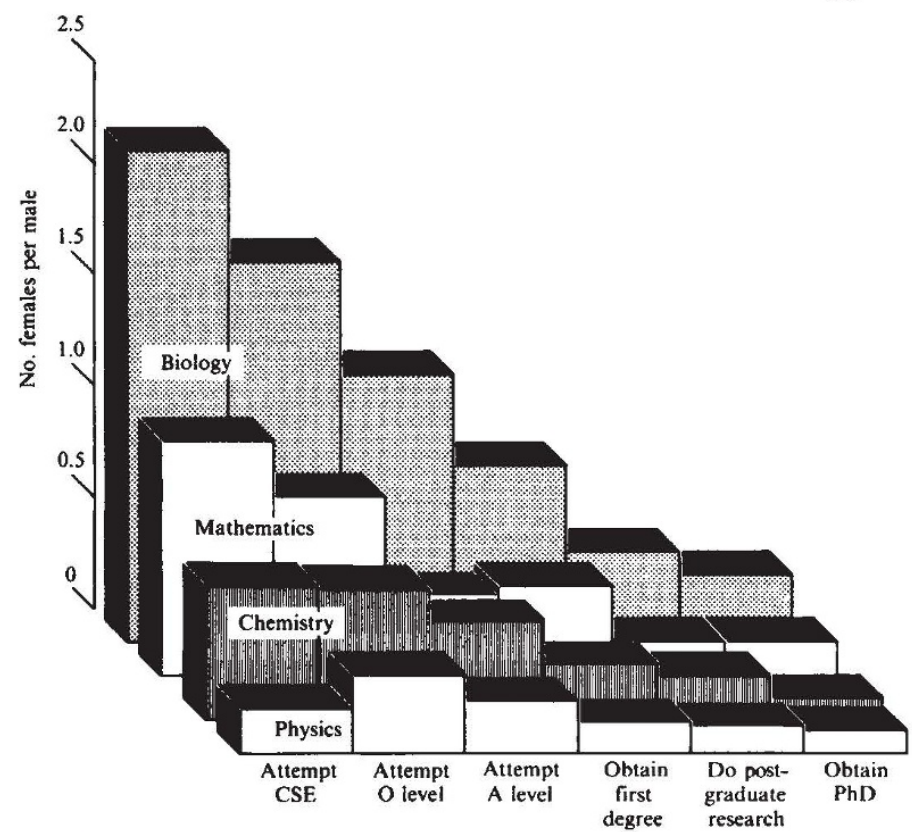

LOOKING at the number of females per male studying individual science subjects at various levels of the education system in England and Wales, it emerges that there are more males than females taking almost every pure science subject at all levels. Only elementary biology is studied by more girls than boys, and even this situation is reversed at degree level. Overall, the same number of girls as boys study science up to the age of 16 , after which female representation progressively lessens until, at the postgraduate level, only one in six of those who obtain a PhD is female.

Source: Institute of Physics.

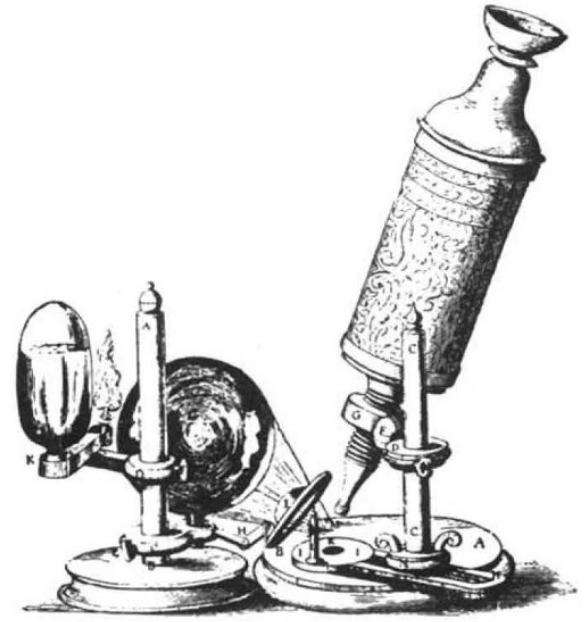

Hooke's microscope, as shown in Micrographia.

circles for his microscopical observations but today his name is more likely to be associated with his law of elasticity or with his work on the Boylean air-pump. His many other inventions and discoveries seem, for the most part, to be forgotten. Who for instance remembers that it was Hooke who invented the marine barometer and the spirit level, and discovered the phenomenon of diffraction?

He was involved in such diverse matters as the manufacture of artificial fibres, the building of a steam engine and a theory of evolution. And after the Great Fire of London he still found time to lay before the Royal Society a model for the re-building of the City. He was by some accounts first with a Gregorian-type reflecting telescope, a reflecting quadrant and a method of regulating watches by a balance spring.

Yet despite his many contributions to science there appears to have been little love lost between him and many of his fellow scientists. It is true that as a Fellow and later as Secretary of the Royal Society he was recognized as a natural philosopher of considerable standing. Yet unsubstantiated charges were made, and repeated ad nauseam, claiming that not only did he set too high a value on much of his work, but also that he claimed as his own the inventions of others.

At least some of the bitterness may have stemmed from Hooke's strenuous opposition to Isaac Newton's hypothesis on the different refrangibility of light rays. It was suggested, somewhat uncharitably, that his opposition had been prompted by the rising reputation of this new philosopher working in a field that Hooke looked on as his own. Hooke was subjected to a barrage of abuse, and to hear himself described as "envious, suspicious and of a natural peevishness of character" did not improve his relationship with his fellow scientists.

But whatever may be said of his disposition, he stands out as a leading personality of the seventeenth century and one of the great inventive minds of all time.

Arthur Frank 